\title{
EXTENSIVE READING IN INDONESIAN SCHOOLS: A SUCCESSFUL STORY
}

\author{
Christina Lhaksmita Anandari ${ }^{\text {a }}$ Yuseva Ariyani Iswandari ${ }^{\text {b }}$ \\ ('1haksmita.anandari@gmail.com; ${ }^{b}$ yuseva.iswandari@gmail.com) \\ Indonesian Extensive Reading Association (IERA) \\ Universitas Sanata Dharma \\ Jalan Mrican Baru, Catur Tunggal, Depok, Kabupaten Sleman, \\ Yogyakarta, Indonesia
}

\begin{abstract}
The low level of literacy of the Indonesian students has become a major nation-wide concern in Indonesia. The 2015 PISA (Program for International Student Assessment) result showed that Indonesian students' literacy level in English was one of the lowest in the world. Gerakan Literasi Nasional (GLN) was established in 2016 as one of the possible solutions to increase the Indonesian students' literacy level. The extensive reading programs done in the schools and in the universities described here is in line with GLN's vision and mission, in that the Extensive Reading programs and activities play a tremendous role in the schools' and communities' effort to create more established, well-planned actions to increase the students' literacy level. Therefore, this paper will discuss two objectives: (1) describing steps to establish a successful Extensive Reading program at Indonesian schools and (2) reporting factors that contribute to the success of an extensive reading program. The findings of this research revealed how extensive reading activities supported the success of GLN through the creation of extensive reading programs within and outside the curriculum, and how schools and home literacy culture could be contributing factors to the success of this program.
\end{abstract}

Keywords: extensive reading, contributing factors, literacy

DOI: http://dx.doi.org/10.15639/teflinjournal.v30i2/137-152

According to the 2015 World Economic Forum, a successful nation should be literate in at least these six components: language literacy, numeracy literacy, 
financial literacy, scientific literacy, ICT literacy, and culture and civic literacy. This is of course a very challenging demand for Indonesia for two main reasons. The first reason is because, demographically, it consists of thousands of islands, hundreds of local languages, and around 270 million people. One can imagine the complexities faced by the government to make sure that the whole nation can achieve the high literacy level in those six areas and receive a fair amount of education, welfare, and opportunities. The second reason is that it cannot be denied that the school system and society as a whole still consider that high scores in mathematics and science determine the students' bright future while reading is viewed as an unimportant aspect of successful learning. This view is represented in the 2015 PISA result, where Indonesian students scored 347 for reading literacy, 403 for science literacy, and 386 for mathematics literacy out of the maximum of 600. In PISA, the tested elements in reading are: retrieving information, forming a broad understanding, developing an interpretation, reflecting on and evaluating the content of a text, and reflecting the form of a text (https://nces.ed.gov/surveys/pisa/index.asp). This test result for reading literacy reflects the fact that Indonesian students aged 9-15 on average have very low ability in comprehending texts. This is obviously a red alert for the whole nation.

The PISA result has become one of the reasons for Indonesia to pay attention to the students' reading literacy level since reading is one of the ways to determine someone's success. Richards in Grabe (2009) stated that, "A person's future opportunities for success and prosperity will be even more entwined with skilled reading abilities" (p. 6). Grabe (2009) also described the benefit of the importance of reading ability for people in the modern era:

Citizens of modern societies must be good readers to be successful. Reading skills do not guarantee success for anyone, but success is much harder to come by without being a skilled reader. The advent of the computer and the Internet does nothing to change this fact about reading. If anything, electronic communication only increases the need for effective reading skills and strategies as we try to cope with the large quantities of information made available to us (p. 5)

These two quotes represent the importance of reading, i.e. a person who reads will be more successful in his/her future life. A successful learner in the $21^{\text {st }}$ century “... must not only possess strong skills in areas such as language arts, mathematics and science, but they must also be adept at skills such as critical thinking, problem-solving, persistence, collaboration and curiosity" 
(World Economic Forum, 2015). In the long run, in order to create a strong and powerful nation, the people should be literate because a literate nation is a nation where its citizens will have the ability to collaborate, think critically, be creative, communicative, which can help the nation to flourish in this globalization era (Atmazaki et al., 2017). Therefore, due to this new challenge, it is imperative that everyone, the government, schools, families, and society, should walk hand in hand to do something to ensure that the nation equips the younger generation to face this disruptive era. Then the question arises: how can we achieve high literacy for our future generations? One of the possible answers would be to create a positive reading environment in schools through an extensive reading program. Therefore, this paper has two objectives: (1) describing steps on establishing a successful extensive reading program at Indonesian schools, and (2) reporting factors that contribute to the success of extensive reading program.

\section{Extensive Reading in the School: EFL Context}

There is a fine line between those who are reading to learn and those who are learning to read. Students who are learning to read means they are still struggling to understand the meaning of the words rather than the content of the text. These types of the students will eventually read more slowly and focus more on vocabulary. Students who are reading to learn are the types of students who are reading books not only for academic purposes, but also for enjoyment. These types of students are students who are independent readers and have developed reading habits (Solihin, Utama, Pratiwi, \& Novirina, 2019).

The Indonesian Government has come to realize that the future generations should be in the phase of learning to read and so they should be exposed more to reading because "...it is important to promote the awareness of how literacy fits with life issues such as career goals and personal fulfillment" (Moore \& Hinchman, 2003, cited in Cohen, 2007, p. 17). Moreover, the future generations of Indonesia should be made aware of the fact that "... reading is something one does to enhance one's life, not just to answer questions at the end of a passage" (Cohen, 2007). In other words, it is a global effort the nation needs to make to realize that a powerful nation should consist of literate and well-read population.

In order to become a well-read nation, the Indonesian government launched Gerakan Literasi Nasional (National Literacy Movement, henceforth 
GLN), a national movement established by the Ministry of Education in 2014 . In 2016, Gerakan Literasi Sekolah (School Literacy Movement, henceforth GLS) and Gerakan Literasi Keluarga (Home Literacy Movement, henceforth GLK) were formed because it was evident that school (teachers, school administrators, and librarians) and family play an enormous role in increasing the children's literacy level. These pinpoint the fact that to increase the current low level of literacy, students need to be surrounded by positive attitudes towards literacy.

In line with the Indonesian government's GLN, the Indonesian Extensive Reading Association (IERA) was established on October 21, 2016 with the help of Dr. Willy Renandya who is on the Executive Board of the Extensive Reading Foundation (ERF). Yuseva Ariyani Iswandari and Christina Lhaksmita Anandari of Sanata Dharma University were appointed as the coordinators. IERA has become one of the seven global ERF affiliates. The main purpose of its establishment is to introduce the concept of English extensive reading to schools and universities as one effective way to help students build the joy of reading. There are three specific programs that have been conducted. The first program is creating a venue for the exchange of information and best practices on ER and its possible joint programs through workshops and roadshows. IERA began its first workshop on May 24, 2016 with two main speakers: Dr. Willy Renandya of Nanyang Technological University and Dionisius Sasmoyo of Tanoto Foundation. Following the success of the workshop, IERA conducted roadshows in several cities in Indonesia in 2018 and 2019. School teachers, university lecturers, practitioners, librarians, teacher trainers, reading communities, and government officials who joined these roadshows were able to have discussions with ERF representatives. The second program is helping schools to establish ER program. IERA supports this program through its ER implementation initiatives with the school students and teachers, book support, and provision of materials. The last program is conducting joint research on the implementation of ER in Indonesia with eleven universities who have become IERA members. The official website of IERA is http://iera-extensivereading.id.

Based on observations and discussion by IERA at schools and with teachers during our series of workshops, it was found that many schools are interested in trying to implement extensive reading programs. However, many of them still do not have a clear idea how to exactly start such a program. The

Extensive Reading Foundation Guide to Extensive Reading 
(http://erfoundation.org/wordpress/guides/) summarizes three steps. First, schools should plan their libraries. It is important to start in a simple way, but they still need to think about how this program can grow in the long run. To enable this, teachers need to consider the following questions stated in the ERF Guide (2011, p. 5):

- How much and how often do students need to read?

- Should teachers allocate time to do this in class? Is there a clear plan for this?

- Should this program be included or excluded in the regular class?

- How many books do schools need to provide in order to manage different levels of abilities and interests?

- How do schools manage the books in the library?

- How do students change their books? How many books do they have to read?

- How do teachers assess the students' reading?

- How do schools find financial support for this?

- Who should take care of this program?

Furthermore, Waring (2006) highlights that the books in the library should be ones that help the students achieve reading gain, not reading pain. Therefore, there should be enough graded readers on the shelves even after some students borrow some of them. For example, if a school has 200 students and each of them borrows one book at a time, the school needs around 300 books. It is because when the 200 books are borrowed, the library still has some spares in the borrowing system and on the shelves.

The second step is setting up the library. Schools need to create a practical system which enables students to understand how to use the library. In order to manage students with various levels of abilities and interests, ERF guide (2011, p. 6) recommends that the library:

- consist of fiction and non-fiction graded readers with age appropriateness

- accommodates various genres and topics, such as detective, drama, romance, thrillers etc.

- provide other types of books at various difficulty levels adjusted with the student population at the schools.

- add books that have potential to be students' favorite in the next some years. 
Categorizing those books according to their levels will also help students decide which books they need to choose. One simple way suggested by ERF Guide is by color code, whereby each book is marked by different colors taped to the spine of the book based on their similar levels (see the level guide on the ERF website that shows how books from various series match in terms of level). In short, as Renandya and Jacobs (2016, p. 3) suggest, schools need to make sure that the reading materials should be appropriate with the students' levels and the contents should be encouraging and engaging.

The last step is introducing what extensive reading is and how to implement it. Teachers can start introducing it in the regular class first by giving a very easy book which students of all levels can read. The main purposes are to help students get the idea of ER, and to discover the joy of reading first, which is important to build their reading motivation. After the students get the concept of ER, teachers can start to allow them to do their selfselected reading, carefully selecting books they can read easily and fluently with high levels of comprehension. Teachers still need to monitor this because for some students, especially in Asian contexts, autonomous reading selection and time are still not familiar (Kirchhoff, 2013, p. 193). Finally, teachers can assign students to read outside the class after several practice sessions in class.

\section{METHOD}

This paper focuses on two objectives: (1) describing steps on establishing a successful ER program at an Indonesian school and (2) reporting factors that contribute to the success of ER program. In this case, the writers refer to their hands-on experience in helping some schools establish extensive reading programs. To achieve the first objective of the study, an interview was carried out with an English teacher at a private vocational high school in Surakarta, Indonesia. He has been teaching English to $11^{\text {th }}$ graders for the past 6 years. Currently, he integrates the school literacy movement in his English class by combining intensive reading and extensive reading. Throughout the academic year, each student was given a task to read three novels and write a journal which would then be submitted to the teacher.

Data on factors that contribute to the success of ER program, which is the second objective of the study, were collected from interviews, field notes and student journals. The interviews were done with two teachers. One was an English teacher at a private junior high school in Yogyakarta, Indonesia. $\mathrm{He}$ 
has been conducting extensive reading program for about 2.5 years with the help of IERA. This teacher is an ER enthusiast and an avid reader himself. He believes in the power of extensive reading and its benefits especially for EFL learners. The other teacher was an English teacher at a public senior high school in Yogyakarta, which became a partner school with the writers' university. The teacher conducted the extensive reading program with the help of IERA as well.

Field notes during the setting up of the extensive reading program at the two schools where the two teachers taught were written to identify what worked well and what needed to be reviewed in establishing an ER program. The field notes helped the writers to see how the theories could be applied into practice. Finally, 72 students' journals of their reading journey were analyzed in order to summarize factors that contribute to the success of this program.

\section{FINDINGS AND DISCUSSION}

\section{Steps for establishing a successful extensive reading program at Indonesian schools}

Establishing a successful extensive reading program requires good teamwork between the school administrators, the teachers, the students, and the community. During an online interview done in January 2019 with the English teacher in Surakarta, it was evident that he understood the importance of extensive reading and how GLS could be used as the platform to establish an extensive reading program in his school. His success of establishing an extensive reading program in his English class was due to a number of reasons: (1) the school administrator's consent; (2) the students' enthusiasm; and (3) book availability.

\section{School support}

The first and foremost stage to create a successful extensive reading program was to gain the full support from the school administrators. Asraf \& Ahmad (2003) revealed in their research that a positive support system from the school enables the program to be beneficial for the school, students, and teachers. In the interview the teacher explained that all teachers in his school were given the opportunity to integrate reading for enjoyment in their 
respective classes. As an English teacher, he saw an opportunity to create a positive literacy environment in his English class by integrating reading English stories/novels in his lesson plans. His main purpose was to give the students an opportunity to be more engaged with the stories that they were reading. In one academic year, each student has to read three short novels and report their reading in their journal books and submit them to him. In his opinion, “... had it not been for the school administrator's support, I would not have been able to do this in my class." The school administrators, in his opinion, were very supportive of this program because they were able to make his class into a role model on how to successfully integrate an extensive reading program through GLS in his English class. Nevertheless, during the interview, he mentioned one example of a challenge faced by his fellow teachers of non-English subjects such as Math, Science, Bahasa Indonesia, and Bahasa Daerah. Their major challenge was the lack of knowledge and sources of books on how to integrate extensive reading program through GLS in their classes.

The challenge confirmed that the first and second steps proposed by the Extensive Reading Program in the ERF's Guide to Extensive Reading are essential. Support from the school administrator should be evident in a way that the school should provide a clear plan of how to plan the library use. One of the suggestions to support the first step is that the administrator should facilitate and give full support in funding the books for the library.

\section{Students' enthusiasm}

A clear plan for setting up the library influences how the teacher implements extensive reading. As was mentioned before, one of the important elements of setting up a library is that teachers should have the capacity to determine the right types of books for the students of different levels and interests. According to Kirchoff (2013), the teachers' ability in determining the book levels and topics will create high enthusiasm for reading in the students. In the interview, he also discussed how the students' enthusiasm played an integral part in his success in implementing the extensive reading program through GLS. In the beginning, the students felt reluctant because their notion of "reading a novel" was already negative, let alone having to report what they had read in their book journal. He said: 
"...the students were a bit reluctant to the idea of reading a novel because they felt that they weren't good readers. They considered themselves as students who would read textbooks to obtain information, not as students who would read novels for enjoyment. They were not used to having the concept of reading without having their comprehension graded."

He made sure that he gave the students "positive pressure" during the extensive reading program. The positive pressure helped motivate the students to read more literary books because he required the students to read at least 3 novels in one semester. As a teacher, he was required to give grades for his students' work because the grades for the students' journal book was one of the criteria to determine the students' passing grade in his English class. Thus, he believed that if the reading activities were graded, the students would be more aware that reading the novels was one of the elements to determine their passing grade in English class and the reading was valuable. Nevertheless, the teacher realized that the way he conducted the class influenced the students' enthusiasm level. His biggest challenge was to maintain the students' enthusiasm and thus he felt the need to search for more teaching techniques that did not negate the students' reading for pleasure. The students' enthusiasm in following the program was a mixture of wanting to read and not wanting to fail the English class.

This condition is in line with the third step of the ERF's guidelines in setting up a successful ER program, which says that it is also the teacher's job to become aware of how to create a "friendly" ER program according to the students' characteristics and needs (p. 6). Robb and Susser (1989) strengthened this belief in that students' enthusiasm and motivation play an important role in enabling them to read enthusiastically.

\section{Book availability}

The next important step in establishing an extensive reading program in a school is resourcing the books. According to Judge (2011), book availability plays an important role in making sure that the school can run the extensive reading program for a long period of time. Throughout the interview, the teacher was very glad that the school had a sufficient number of fiction books in the library. Therefore, there were no reasons for them to not find any novels to read. However, he was somewhat concerned with the available books because the books were unabridged novels, and therefore the program was 
quite challenging for some students who had low English proficiency level. He explained that although he required the students to read short novels, he often found some students were struggling to read thick novels because those were the only novels available (other short novels were already borrowed by their classmates). He already communicated this to the library and to the school, but unfortunately, due to the financial condition, the school could not yet purchase graded reader books, or leveled books. Nevertheless, despite these hindrances, he realized that at least, the English books provided in the library would help him in conducting the extensive reading program through GLS.

However, the writers found out that the books that the teacher used in his class were not appropriate to accommodate the different levels of the students. The teacher also mentioned that the low proficiency students still struggled to finish the novels. He claimed that he lacked resources, so he had to use any available reading materials found in the library. Helsper and Eynon (2010) described that we were now living in the young internet culture, which means the young generation read internet and use gadgets more frequently than physical books. Robb (2018) also emphasizes that online sources for teachers and students to download and read are now available. This is good news because graded readers are already published online and some of them are open access and free, such as:

- www.er-central.com

- www.lextutor.ca

- www.letsreadasia.org

- www.en-hon.jp

With this easy access to free online graded materials, the writers are more optimistic that book availability is not an issue anymore in implementing the extensive reading program.

\section{Factors that contribute to the success of extensive reading program at Indonesian schools}

The second objective of the study emphasizes the factors that contribute to the success of an extensive reading program in Indonesian schools. Based on the analysis of the writers' field notes taken while setting up extensive reading programs at schools and of the students' journals on their reading journey, three major contributing factors to the success of extensive reading program at Indonesian schools emerged, as follows. 


\section{Home literacy culture}

Several studies found a strong relationship between home literacy culture and students' reading habit and their positive attitudes towards reading (e.g. Baker, Scher, \& Mackler, 1997; Jordan, Snow, \& Porche, 2000; Takase, 2007). Furthermore, Cunningham and Stanovich (1997) state that the reading atmosphere created by parents at home becomes an early influence on a good reading habit. Parents who read regularly near their children at home can stimulate the children's engagement with reading and attract children to also read. One of the student participants in this study revealed in her journal as follows:

Display replies in nested form

Move this discussion to ... Move

Reading Habit 10.50 PM

Back then when I was still in elementary school, I dont remember exactly at what age, I still slept in the same room as my parents. Every night before we go to bed my father used to ask me to grab two books, one for me and one for him. The book was from the Lima Sekawan series which have become my favorite novel up until no

The novel was written in Indonesian but it had English names like George, Anne, etc, so I always asked my father how to pronounce them. Whenever I found new words I asked my mother the meanings and definitions of them.

As I grew up my parents became busier so they could no longer read books with me, so I started reading alone. I was a huge fan of comic books, but then when I entered junior high school I started reading e-books on Wattpad and I even wrote and published my own stories there.

Around the second year of junior high school I started reading and writing English books on Wattpad. When I started writing my parents and my friends supported me a

On the third year of junior high school I began saving up to buy English novels. I had to stay away from the school cafeteria to save up as English books tend to be pricey.

The first English books that I bought was the Divergent series ; Divergent, Insurgent, and Allegiant. These series were so fun and exciting to read. I started reading books from the same genre since then, such as The Maze Runner, The Hunger Games, etc. Then I started to try reading romance novels like The Fault in Our Stars and Paper Towns.

You see, as I list those English books I've read, I feel satisfied and proud. I feel like finishing an English book and knowing that I understand the whole content of it is an achievement. It is something to be proud of as I get to gather more information from reading. Reading widens my knowledge and gives me some sort of confidence in a way I can't really explain.

If it weren't because of my parents accompanying me to read back then I would've not developed this reading habit.

\section{Figure 1. A Student's Journal on Her Home Literacy Culture}

This shared reading experience between this student and her parents that is introduced and developed at home plays a significant role in the success of her reading for enjoyment habit. Yamashita (2013, p. 249) states that "readers' individual experiences influence their decision to read".

The opposite story was presented by another student participant who did not encounter a good reading culture at home:

Actually, I don't like reading because I think reading is boring although my English teacher in senior high school keeps telling me that reading is important. My parents never bought story books when I was a kid. They only provided 
newspapers, but I seldom saw them reading at home, they were too busy working. Now, I really have to struggle when you ask us to read articles or graded readers. They are just too difficult for me.

Those two stories that revealed different situations at home show that the parents' beliefs about literacy and their own literacy practices at home can predict the students' reading engagement at school (Foy \& Mann, 2003). Based on the analysis of the student participants' journals, the writers concluded that students whose home literacy culture was strongly built could engage in the extensive reading program well.

\section{Teacher modelling}

Modelling is described as "the patterning of thoughts, beliefs, strategies, and actions displayed by one or more models - usually teachers who explain and demonstrate skills" (Schunk \& Zimmerman, 1997, as cited in Loh, 2009, p. 95). The simple way to say this is "You read I read" rule; which means that when the teachers assign the students to read, the teachers themselves also read. Teachers who show the students that they enjoy reading will stimulate the students' belief and thinking that reading is enjoyable and valuable. Guthrie, Dreher, and Baker (2000) claim that in order to develop students who are highly engaged readers, teachers also need to be highly engaged in reading. This similar thought was also shared by one of the teachers interviewed, who implemented an extensive reading program with the help of IERA. In the interview, he stated:

Before starting the program, IERA mentioned that I, as the teacher, should model reading to my students. Therefore, I also read during the silent reading session. I chose my own book, sat down near my students and read. The reaction was amazing. My students were gradually silent, chose their own spot, and read.

The other teacher also did the same thing, but she did not only model reading during the extensive reading session, as stated in the interview:

I brought my favorite book or book that I was reading to the class. I was reading "I am Malala", so I brought the book to my class. Some female students came to me and asked about the book, maybe because the cover was about a girl. They were curious. They borrowed it, and after two weeks, they invited me to discuss the story. Since that day, I always brought my book to class. 
Both teachers showed what Nuttall (1982, p. 192) mentions that "readers are made by readers". They were able to convince the students to read because they themselves also read and recommended books to their students.

\section{Consistency of the program}

The efforts made by a school in implementing extensive reading programs would not work well if it lacks consistent support for the reading from both teachers and parents. Krashen's (2004) research findings show that after implementing extensive reading for one full year, extensive reading seems to have stronger reading effects on the students. One of the effects is stated by Grabe (2009) who claims that doing extensive reading consistently leads to students' improvement of their own language learning. In the interview, the two English teachers explained how they kept the consistency of the extensive reading program.

One of the teachers interviewed said that he provided a consistent schedule and exposure to his students to conduct extensive reading outside the class. He set up a regular meeting every Tuesday from 1.30 to $3 \mathrm{pm}$ for one whole year and made this extensive reading a mandatory extracurricular activity. He designed a lesson plan, covering the step-by-step plans of activities in every meeting, and consulted IERA about it. He also made sure that there was easy access to better reading materials and, therefore, he wrote a proposal to the school administrator to purchase graded readers. He stated that the book availability in the school library became his "mood booster" to keep the program running consistently until now.

The other teacher interviewed, on the other hand, did not get permission from both the school administrator and the parents for the extracurricular extensive reading program. Therefore, she integrated this program into her English class hours. She stated:

My school administrator did not allow me to keep students at school doing this program. He said that students have enough burden and homework from school. Besides, parents do not want their children to stay longer at school since they also have their own life after school. So, I implemented it during my English class.

She continued explaining that she made it flexible during her English class. She sometimes invited students to read for pleasure in the first 15 minutes. She let students choose their own book and asked them to 'drop 
everything and read'. After that, she would let students share their reading through several follow up activities, such as literature circles, book recommendations, etc. When she had more time, she invited students to do more follow-up activities, like gallery walks or creating art from the reading. She also used the graded readers to support the intensive reading that she had to teach to her students. At the end of the semester, she asked the students to perform a role play in groups.

\section{CONCLUSIONS}

This paper discussed the necessary steps for establishing a successful extensive reading program at Indonesian schools and the factors that contribute to the success of extensive reading program. The findings revealed that getting the support of the school, especially when planning a library, was an important first step to setting up a successful extensive reading program. The next step was setting up the library, which required teachers to be able to help students determine the book levels and topics. It was found that when students chose books appropriately for their levels and interests, their enthusiasm for reading increased. Therefore, book availability was crucial to support the success of this extensive reading program in the long run.

The next finding concerned the factors that contributed to the success of the extensive reading program. A home literacy culture was identified as greatly contributing to how students responded towards the extensive reading. Those who were exposed to reading at home from an early age would respond more positively and read independently and better than those who did not have reading experiences at home. Moreover, the teachers who modeled reading, both inside and outside the classroom, were able to better convince students to believe that reading was important and enjoyable. Finally, the consistency of the program made the students' attitudes towards reading more positive.

\section{REFERENCES}

Atmazaki, Ali, N. B. V., Muldian, W., Miftahussururi, Hanifah, N., Nento, M. N., \& Akbari, Q. S. (2017). Panduan Gerakan Literasi Nasional [National Literacy Movement guidelines]. Jakarta: Kementrian Pendidikan dan Kebudayaan. 
Asraf, R. M., \& Ahmad, I. S. (2003). Promoting English language development and the reading habit among students in rural schools through the Guided Extensive Reading program. Reading in a Foreign Language, 15(2), 83102.

Baker, L., Scher, D., \& Mackler, K. (1997). Home and family influences on motivation for reading. Educational Psychologist, 32(2), 69-82.

Cohen, J. (2007). A case study of a high-school English-language learner and his reading. International Literacy Association, 51(2), 164-175.

Cunningham, A. E., \& Stanovich, K. E. (1997). Early reading acquisition and its relation to reading experience and ability 10 years later. Developmental Psychology, 33(6), 934-945.

Extensive Reading Foundation (n.d.), Guide to extensive reading. Retrieved from: https://erfoundation.org/guide/ERF_Guide.pdf

Foy, J. G., \& Mann, V. (2003). Home literacy environment and phonological awareness in preschool children: Differential effects for rhyme and phoneme awareness. Applied Psycholinguistics, 24, 59-88.

Guthrie, J. T., Dreher, M. J., \& Baker, L. (2000). Why teacher engagement is important to student achievement. In L. Baker, M. J. Dreher, \& J. T. Guthrie (Eds.), Engaging young readers: Promoting achievement and motivation (pp. 309-320). New York: Guilford Press.

Grabe, W. (2009). Reading in a second language: Moving from theory to practice. Cambridge: Cambridge University Press.

Helsper, E. J., \& Eynon, R. (2010). Digital natives: Where is the evidence? British Educational Research Journal, 36(3), 503-520.

Jordan, G. E., Snow, C. E., \& Porche, M. V. (2000). Project EASE: The effect of a family literacy project on kindergarten students' early literacy skills. Reading Research Quarterly, 35(4), 524-546.

Judge, P. B. (2011). Driven to read: Enthusiastic readers in a Japanese high school's extensive reading program. Reading in a Foreign Langauge, 23(2), 161-186.

Kirchhoff, C. (2013). L2 extensive reading and flow: Clarifying the relationship. Reading in a Foreign Language, 25(2), 192-212.

Krashen, S. D. (2004). The power of reading (2nd ed.). Portsmouth, NH: Heinemann.

Loh, J. K. K. (2009). Teacher modeling: Its impact on an extensive reading program. Reading in a Foreign Language, 21(2), 93-118. 
Nuttall, C. (1982). Teaching reading skills in a foreign language. London: Heinemann.

Renandya, W. A., \& Jacobs, G. M. (2016). Extensive reading and listening in the L2 classroom. In W. A. Renandya \& H. P. Widodo (Eds.), English language teaching today (pp. 97-110). New York, NY: Routledge.

Robb, T. (2018). An introduction to online sites for Extensive reading. The Electronic Journal for English as a Second Language, 22(1), 1-16.

Robb, T. \& Susser, B. (1989). Extensive reading vs. skills building in EFL context. Reading in a Foreign Language, 5(2), 239-251.

Solihin, L., Utama, B., Pratiwi, I., \& Novirina. (2019). Indeks aktivitas literasi membaca 34 provinsi [Reading literacy activity index in 34 provinces]. Jakarta: Pusat Penelitian Kebijakan Pendidikan dan Kebudayaan, Badan Penelitian dan Pengembangan, Kementerian Pendidikan dan Kebudayaan.

Takase, A. (2007). Japanese high school students' motivation for extensive reading. Reading in a Foreign Language, 19(1), 1-18.

Waring, R. (2006). Why extensive reading should be an indispensable part of all language programmes. The Language Teacher, 30 (7), 44-47.

World Economic Forum (2015). New vision for education: Unlocking the potential of technology. Retrieved from www.weforum.org.

Yamashita, J. (2013). Effects of extensive reading on reading attitudes in a foreign language. Reading in a Foreign Language, 25(2), 248-263. 